\title{
VACCINATION OF RABBITS AGAINST TRICHOPHYTOSIS - AN EXPERIMENTAL STUDY
}

\author{
A. RYBNIKÁŔ, J. CHUMELA, V. VRZAL, J. NEPEŘENÝ \\ Bioveta Plc., Ivanovice na Hané \\ Received March 17, 1998 \\ Accepted June 5, 1998
}

\begin{abstract}
Rybnikář, A., J. Chumela, V. Vrzal, J. Nepeřený: Vaccination of Rabbits against Trichophytosis - An Experimental Study. Acta vet. Brno 1998, 67: 121-125.

Protective efficacy of TRICHOPELEN, a vaccine containing a living Trichophyton mentagrophytes strain, against experimental infection with $T$. mentagrophytes strain proved good. The vaccine showed a satisfactory effect after i.m. administration to 4-month old rabbits and after s.c. administration to 11- to 14-day old rabbits. The efficacy of TRICHOBEN AV, a vaccine containing a living $T$. verrucosum strain, against the heterologous species $T$. mentagrophytes was unsatisfactory. The vaccination T. mentagrophytes strain survived in the inoculated muscle of experimental rabbits for 9 to 10 days. Examination of the lungs, liver, kidney, spleen, lymph node and blood samples for the presence of the vaccination strain yielded negative results.
\end{abstract}

Trichophyton mentagrophytes, immunization, challenge, survival of the vaccination strain

Trichophyton mentagrophytes has been indicated as the main causative agent of skin mycoses in rabbits by a number of writers (B anks and Clarkson 1967; Nikiforov 1980; Englund et al. 1990). This species has been found by us to be the cause of the disease in several cases in large rabbit flocks in the Czech Republic (see Plate X., Fig. 1 and 2). In a major focus of trichophytosis the use a specific vaccine has proved to be one of the most effective means of controlling this infection (Rybnikář et al. 1995).

The present study was designed to find whether the vaccine TRICHOPELEN would confirm its good protective efficacy in rabbits challenged in a laboratory experiment. Another objective was to find whether a satisfactory protection of rabbits against infection with T. mentagrophytes could also be obtained with TRICHOBEN AV, a vaccine containing a $T$. verrucosum strain. Furthermore, we tested the possibility of using TRICHOPELEN in 11- to 14-day old rabbits and examined their organs and tissues for the presence of the vaccination $T$. mentagrophytes strain.

\section{Materials and Methods}

The experimental animals were Large Chinchilla and Bohemian Pied rabbits from flocks without a history of trichophytosis.

In experiment 1 , rabbits aged 4 months were divided into three groups:

Group 1 animals were vaccinated i.m. twice into the hind limb muscle with $0.5 \mathrm{ml}$ doses of TRICHOPELEN, a lyophilized vaccine, containing a living $T$. mentagrophytes var. mentagrophytes CCM 8168 strain (manufactured by Bioveta Plc., Ivanovice na Hané).

Group 2 animals were vaccinated i.m. twice into the hind limb muscle with $0.5 \mathrm{ml}$ doses of TRICHOBEN AV, a lyophilized vaccine containing a living $T$. verrucosum strain (manufactured by Bioveta Plc.. Ivanovice na Hané).

Address for correspondence:

RNDr. A. Rybnikár

Bioveta. a.s.

68323 Ivanovice na Hané

Ceská republika

Phone: + 420507363321

Fax: + 420507363294 
The interval between vaccination and revaccination in Groups 1 and 2 was 8 days.

Group 3 received no vaccination and served as controls.

One month after revaccination the rabbits of the three groups were challenged with field virulent Trichophyton mentagrophytes var. mentagrophytes strain No. ML-94 (isolated from diseased rabbits). The suspension of challenge culture was inoculated into an $8 \times 8 \mathrm{~cm}$ area of clipped and gently scarified skin of the back region at the rate of about $600000 \mathrm{CFU}$ per animal. The rabbits were then observed for clinical skin changes for 30 days after challenge.

In Experiment 2, a total of 7 rabbits aged 11 to 14 days were each vaccinated s.c. with $0.25 \mathrm{ml}$ of TRICHOPELEN into the region behind the shoulder blade and revaccinated s.c. with the same dose of the vaccine on the opposite side of the body 8 days later. One month after revaccination the 7 immunized rabbits and 6 equally old nonimmunized controls were challenged in the same way as in Experiment 1.

At the end of the two experiments ( 30 days after challenge) skin lesion or haircoat specimens were collected from the challenge site from all the rabbits for examination by culture and for microscopic examination (R y bnikár 1992 ).

In Experiment 3, rabbits were vaccinated i.m. at 4 months of age with $1 \mathrm{ml}$ of TRICHOPELEN into the left hind limb muscle and revaccinated i.m. with the same dose of the vaccine into the right hind limb muscle 8 days later. The animals were then killed and subjected to post-mortem examination at $7,10,14,17$ and 22 days after vaccination (2, 6, 9 and 14 days after revaccination). Specimens were taken of the lungs, liver, kidney, spleen, antegenual lymph node. blood collected from the heart and of the muscle at the site of the vaccine administration to be examined for the presence of the vaccination $T$. mentagrophytes strain. The tissue specimens were inoculated into Sabouraud's glucose-peptone agar containing actidion and chloramphenicol and incubated in the dark at $28^{\circ} \mathrm{C}$ for 20 days.

\section{Results}

Results of the protective efficacy of TRICHOPELEN and TRICHOBEN AV vaccines against experimental trichophytosis ( $T$. mentagrophytes) are shown in Table 1 . Rabbits vaccinated with TRICHOPELEN responded to challenge by development of generally slight dermal changes which subsided quickly between 20 and 26 days after challenge. All the animals showed new healthy haircoat and recovered (Plate XI., Fig. 3).

Table 1

Vaccination of four-month old rabbits against trichophytosis.

Challenge with $T$. mentagrophytes culture

\begin{tabular}{|c|c|c|c|c|c|c|}
\hline \multirow[t]{2}{*}{ Experimental group } & \multirow{2}{*}{$\begin{array}{l}\text { Rabbit } \\
\text { No. }\end{array}$} & \multicolumn{5}{|c|}{$\begin{array}{l}\text { Skin mycotic changes after challenge } \\
\text { Days after challenge }\end{array}$} \\
\hline & & Day 6 & Day 12 & Day 20 & Day 26 & Day 30 \\
\hline $\begin{array}{l}\text { Vaccination with } \\
\text { TRICHOPELEN } \\
\text { (T. mentagrophytes) }\end{array}$ & $\begin{array}{r}7 \\
8 \\
10 \\
11 \\
12 \\
13 \\
14 \\
15\end{array}$ & $\begin{array}{l}+ \\
+ \\
+ \\
+ \\
+ \\
+ \\
+ \\
+\end{array}$ & $\begin{array}{r}+ \\
+ \\
++ \\
+ \\
+ \\
++ \\
+ \\
+\end{array}$ & $\begin{array}{l}- \\
- \\
+ \\
\pm \\
+ \\
+ \\
\pm \\
-\end{array}$ & $\begin{array}{l}\bar{z} \\
\bar{z} \\
\bar{z} \\
\overline{ \pm} \\
\bar{z} \\
-\end{array}$ & $\begin{array}{l}\bar{z} \\
\bar{z} \\
\bar{z} \\
\bar{z} \\
\bar{z}\end{array}$ \\
\hline $\begin{array}{l}\text { Vaccination with } \\
\text { TRICHOBEN AV } \\
\text { (T. verrucosum) }\end{array}$ & $\begin{array}{r}1 \\
2 \\
3 \\
4 \\
5 \\
6 \\
18 \\
21\end{array}$ & $\begin{array}{l} \pm \\
\pm \\
- \\
\pm \\
- \\
\pm \\
- \\
+\end{array}$ & $\begin{array}{c}++ \\
+ \\
+ \\
+ \\
+ \\
+ \\
++ \\
++\end{array}$ & $\begin{array}{c}++ \\
++ \\
++ \\
++ \\
+ \\
++ \\
++ \\
++ \\
++\end{array}$ & $\begin{array}{r}+++ \\
++ \\
++ \\
+++ \\
+ \\
++ \\
++ \\
++ \\
++\end{array}$ & $\begin{array}{r}+++ \\
+ \\
+ \\
+++ \\
\pm \\
++ \\
+++ \\
+\end{array}$ \\
\hline $\begin{array}{l}\text { Non-vaccinated } \\
\text { controls }\end{array}$ & $\begin{array}{l}23 \\
24 \\
25 \\
81 \\
82 \\
83\end{array}$ & $\begin{array}{l}- \\
\pm \\
\pm \\
+ \\
\pm \\
-\end{array}$ & $\begin{array}{r}+ \\
++ \\
+ \\
++ \\
+++ \\
+\end{array}$ & $\begin{array}{r}+ \\
++ \\
++ \\
+++ \\
++ \\
++ \\
++\end{array}$ & $\begin{array}{r}+ \\
++ \\
+++ \\
+++ \\
++ \\
+++ \\
+++\end{array}$ & $\begin{array}{r}+ \\
++ \\
+++ \\
+++ \\
++ \\
+++\end{array}$ \\
\hline
\end{tabular}

No skin mycotic changes

$\pm \quad$ Minute skin changes - papulae, scales

$+\quad$ Solitary mycotic foci

+ Mycotic foci covering a $1 / 4-1 / 2$ of the inoculated area

+++ Mycotic foci covering more than half of the inoculated area 
Table 2

Vaccination of 11- to 14-day old rabbits against trichophytosis. Challenge with $T$. mentagrophytes culture

\begin{tabular}{|c|c|c|c|c|c|c|c|}
\hline \multirow[t]{2}{*}{ Experimental group } & \multirow{2}{*}{$\begin{array}{c}\text { Rabbit } \\
\text { No. }\end{array}$} & \multirow{2}{*}{$\begin{array}{c}\text { Age } \\
\text { at the 1st } \\
\text { vaccination } \\
\text { (days) }\end{array}$} & \multicolumn{5}{|c|}{$\begin{array}{l}\text { Skin mycotic changes after challenge } \\
\text { Days after challenge }\end{array}$} \\
\hline & & & Day 6 & Day 12 & Day 20 & Day 26 & Day 30 \\
\hline $\begin{array}{l}\text { Vaccination with } \\
\text { TRICHOPELEN } \\
\text { (T. mentagrophytes) }\end{array}$ & $\begin{array}{r}71 \\
72 \\
84 \\
85 \\
92 \\
96 \\
100\end{array}$ & $\begin{array}{l}14 \\
14 \\
14 \\
14 \\
11 \\
11 \\
14\end{array}$ & $\begin{array}{l}+ \\
+ \\
+ \\
+ \\
+ \\
+ \\
+\end{array}$ & $\begin{array}{r}+ \\
++ \\
++ \\
++ \\
+ \\
+ \\
++\end{array}$ & $\begin{array}{l}- \\
+ \\
\pm \\
+ \\
\pm \\
\pm \\
-\end{array}$ & $\begin{array}{l}- \\
- \\
- \\
\pm \\
- \\
- \\
-\end{array}$ & $\begin{array}{l}- \\
- \\
- \\
- \\
- \\
- \\
-\end{array}$ \\
\hline $\begin{array}{l}\text { Non-vaccinated } \\
\text { controls }\end{array}$ & $\begin{array}{l}74 \\
76 \\
79 \\
80 \\
98 \\
99\end{array}$ & $\begin{array}{l}14 \\
14 \\
14 \\
11 \\
11 \\
11\end{array}$ & $\begin{array}{l}+ \\
\pm \\
\pm \\
+ \\
- \\
\pm\end{array}$ & $\begin{array}{r}++ \\
+++ \\
++ \\
+++ \\
++ \\
++\end{array}$ & $\begin{array}{r}++ \\
++ \\
++ \\
+++ \\
+ \\
++\end{array}$ & $\begin{array}{r}++ \\
++ \\
++ \\
+++ \\
+ \\
++\end{array}$ & $\begin{array}{r}+ \\
++ \\
++ \\
+++ \\
+ \\
+\end{array}$ \\
\hline
\end{tabular}

For explanation of the signs,,,- \pm+++ and +++ see Table 1 .

Non-vaccinated controls responded to the same challenge dose by development of marked trichophytic lesions which persisted throughout the experiment. In some heavily affected controls painful bloody spots were observed after the crusts had come off and no tendency to healing was recorded (Plate XI., Fig 4).

In rabbits vaccinated with TRICHOBEN AV the course of experimental infection after challenge was in nearly all of them similar to that seen in the controls.

Likewise in Experiment 2 (Table 2) the non-vaccinated controls showed the first clinical skin mycotic changes from Day 6 after challenge and the trichophytic foci could be observed till the end of the experiment. In the group of rabbits immunized with TRICHOPELEN at 11 to 1.4 days of age mycotic changes were observed between 6 and 20 days after challenge and then disappeared rapidly.

The results of examination by culture as well as by microscopic examination conducted 30 days after challenge were in keeping with the clinical findings in both experiments.

In Experiment 3 culture attempts to recover the vaccination T. mentagrophytes strain from the lungs, liver, kidney, spleen, lymph node and blood samples yielded invariably negative results. A positive result was recorded only upon examination of the muscle at the injection site. Living elements of the vaccination strain were detected by culture up to 10 days at the site of the first administration of the vaccine and up to 9 days at the site of revaccination. When examined by culture 14 days after vaccination and 14 days after revaccination the inoculated muscle proved negative (Table 3 ).

\section{Discussion}

Vaccination of rabbits and other fur-bearing animals against trichophytosis was not a common practice some 15 years ago. In 1984 MENTAVAK, a Russian commercial vaccine, became available and since then has found wide application (Sarkisov and Nikiforov 1988, Sarkisov and Kolesnikov 1989). The Czech commercial vaccine 
Table 3

Survival of T. mentagrophytes vaccination strain in the inoculated muscle of experimental rabbits

\begin{tabular}{|c|c|c|c|c|}
\hline \multirow{2}{*}{$\begin{array}{l}\text { Rabbit } \\
\text { No. }\end{array}$} & \multirow{2}{*}{$\begin{array}{c}\text { Days } \\
\text { after } \\
\text { vaccination }\end{array}$} & \multirow{2}{*}{$\begin{array}{l}\text { Days } \\
\text { after } \\
\text { revaccination }\end{array}$} & \multicolumn{2}{|c|}{$\begin{array}{l}\text { Mycological findings in the inoculated muscle } \\
\text { at the site of }\end{array}$} \\
\hline & & & vaccination & revaccination \\
\hline $\begin{array}{l}53 \\
54 \\
60 \\
61\end{array}$ & $\begin{array}{l}7 \\
7 \\
7 \\
7\end{array}$ & & $\begin{array}{l}+ \\
+ \\
+ \\
+\end{array}$ & \\
\hline $\begin{array}{l}45 \\
66 \\
70 \\
78\end{array}$ & $\begin{array}{l}10 \\
10 \\
10 \\
10\end{array}$ & $\begin{array}{l}2 \\
2 \\
2 \\
2\end{array}$ & $\begin{array}{l}- \\
+ \\
+ \\
+\end{array}$ & $\begin{array}{l}+ \\
+ \\
+ \\
+\end{array}$ \\
\hline $\begin{array}{l}57 \\
58 \\
65 \\
67 \\
69 \\
75\end{array}$ & $\begin{array}{l}14 \\
14 \\
14 \\
14 \\
14 \\
14\end{array}$ & $\begin{array}{l}6 \\
6 \\
6 \\
6 \\
6 \\
6\end{array}$ & $\begin{array}{l}- \\
\overline{-} \\
\overline{-} \\
\overline{-}\end{array}$ & $\begin{array}{l}+ \\
+ \\
+ \\
+ \\
+ \\
+\end{array}$ \\
\hline $\begin{array}{l}46 \\
55 \\
56 \\
73\end{array}$ & $\begin{array}{l}17 \\
17 \\
17 \\
17\end{array}$ & $\begin{array}{l}9 \\
9 \\
9 \\
9\end{array}$ & $\begin{array}{l}- \\
\overline{-} \\
\overline{-}\end{array}$ & $\begin{array}{l}+ \\
+ \\
+\end{array}$ \\
\hline $\begin{array}{l}59 \\
62 \\
68 \\
77\end{array}$ & $\begin{array}{l}22 \\
22 \\
22 \\
22\end{array}$ & $\begin{array}{l}14 \\
14 \\
14 \\
14\end{array}$ & $\begin{array}{l}\bar{z} \\
\bar{z} \\
\bar{z}\end{array}$ & $\begin{array}{l}- \\
- \\
-\end{array}$ \\
\hline
\end{tabular}

- Negative finding upon examination by culture

+ Positive finding of the vaccination $T$. mentagrophytes strain

TRICHOPELEN, available since 1992, has also been widely used in veterinary practice. Very good results obtained with TRICHOPELEN in silver foxes and arctic foxes have been reported (Rybnikár et al. 1991). Its high protective efficacy was also demonstrated in the present study. The protection of vaccinated rabbits against experimental infection became clearly evident, compared with non-vaccinated controls.

Trichophytic infections are known to endanger even young rabbits in the first days after birth. Clinical signs of trichophytosis have been described in rabbits between 14 and 18 days of age (Sarkisov and Nikiforov 1981; Rybnikár et al. 1995). From the results reported here it appears that the incubation period in rabbits infected experimentally with T. mentagrophytes culture may be as long as 6 days (Tables 1 and 2). Therefore we tested the possibility of immunizing rabbits at an early age. In view of the insufficiently developed limb muscle in 11- to 14-day old rabbits we administered TRICHOPELEN subcutaneously (in instructions for its use intramuscular administration is recommended). Even under these conditions the protective efficacy of the vaccine proved very good, being quite comparable with the results obtained in 4-month old rabbits. This is in keeping with our previous observations. From similar experiments conducted with TRICHOBEN in cattle it appears that reliable immunity against trichophytosis can be obtained even upon vaccination of the youngest age categories (Rybnikář et al. 1993).

Of interest have been the findings concerning cross immune reactions in dermatophytes. Calves immunized with a living $T$. verrucosum strain have shown good protection against experimental infection with T. mentagrophytes (Rybnikár 1992). In an analogous 
experiment conducted in the present study with TRICHOBEN AV ( $T$. verrucosum) on rabbits a sufficient degree of protection was not obtained. As in our previous report (R ybnikár et al. 1996) it became evident that a preparation highly effective in one animal species may not produce a satisfactory immunizing effect against the same infection in another animal species.

After intramuscular administration of TRICHOPELEN we recorded no spread of living elements of the vaccination $T$. mentagrophytes strain from the injection site. The vaccination strain could be recovered by culture from the inoculated muscle for no more than 10 days after inoculation. Similar results have been obtained in experiments with two vaccines against trichophytosis in cattle: $T$. verrucosum vaccination strains survived in guinea-pig muscle for 5 to 10 days (Hejtmánek et al. 1986). The afore-mentioned observations are important particularly with regard to the determination of withdrawal periods during which meat from vaccinated animals cannot be used for human consumption.

\section{Vakcinace králíků proti trichofytóze - experimentální studie}

Protektivní účinnost vakcíny TRICHOPELEN (obsahuje živý kmen Trichophyton mentagrophytes) proti experimentální infekci kmenem $T$. mentagrophytes byla dobrá. Vakcína prokázala vyhovující efekt po intramuskulární aplikaci čtyřměsíčním králíkủm i po subkutánní aplikaci 11-14 denním králíčkům. Účinnost vakcíny TRICHOBEN AV (živý vakcinační kmen $T$. verrucosum) proto heterolognímu druhu $T$. mentagrophytes byla nedostačující.

Vakcinační kmen $T$. mentagrophytes přežíval v inokulované svalovině králíků po dobu 9-10 dnů. Vyšetření tkání plic, jater, ledvin, sleziny, mízní uzliny a krve na přítomnost vakcinačního kmene bylo negativní.

\section{References}

BANKS, K. L., CLARKSON. T. B. 1967: Naturally occurring dermatomycosis in the rabbit. J. Am. Vet. Med. Assoc. 151: 926-929

ENGLUND, L., MATTSON, R., BERNDTSON, L. T. 1990: Possible effect of vaccination against Trichophyton mentagrophytes infection in a Swedish fox farm. Acta vet. scand. 31: 121-123

HEJTMÂNEK, M., KOD́OUSEK, R., WEIGL, E., RYBNIKÁŔ, A., VRZAL, V., CHUMELA J. 1986: Tissue reaction in guinea pigs after intramuscular application of living vaccine against trichophytosis. Acta Univ. Palack. Olomuc., Fac. Med. 114: 171-185

NIKIFOROV, L. I. 1980: Vozbuditel dermatomikoza pušnych zverej, krolikov i laboratornych životnych. Veterinarija (Moskva) (11): 39

RYBNIKÁR, A. 1992: Cross-immunity in calves after vaccination against trichophytosis. Acta vet. Brno 61: 189-194

RYBNIKÁŘ, A., CHUMELA, J., VRZAL, V., KRYS, F., JANOUŠKOVCOVÁ, H. 1991: Prophylactic and therapeutic use of a vaccine against trichophytosis in a large herd of silver foxes and arctic foxes. Acta. vet. Brno 60: $285-288$

RYBNIKÁR, A., VRZAL, V.. CHUMELA, J. 1993: Vaccination of young calves against trichophytosis. Acta Vet. Brno 62: 55-61

RYBNIKÁR̆, A., VRZAL, V.. CHUMELA, J. 1996: Vaccination of dogs and calves against Microsporum canis. Acta vet. Brno 65: 161-164

RYBNIKÁR, A., VRZAL, V., CHUMELA, J., KOVÁŘ, S. 1995: Trichofytóza ve velkochovu králíků. Veterinářství 45: 19

SARKISOV, A. CH., KOLESNIKOV, A. J. 1989: Osnovnye puti iskorenenija dermatomikozov. Veterinarija (Moskva) (12): 36-38

SARKISOV, A. CH., NIKIFOROV, L. I. 1981: Specifičeskaja profilaktika trichofitii pušnych zverej. Veterinarija (Moskva) (7): 37-38

SARKISOV, A. CH., NIKIFOROV, L. I. 1988: Mentavak vakcina házinyulak és prémes állatok trichophytiasisának megelözésére és gyógykezelésére. Phylaxia 24: 126-128 
Plate X.

Rybnikář A. et al.: Vaccination... pp. 121-125.

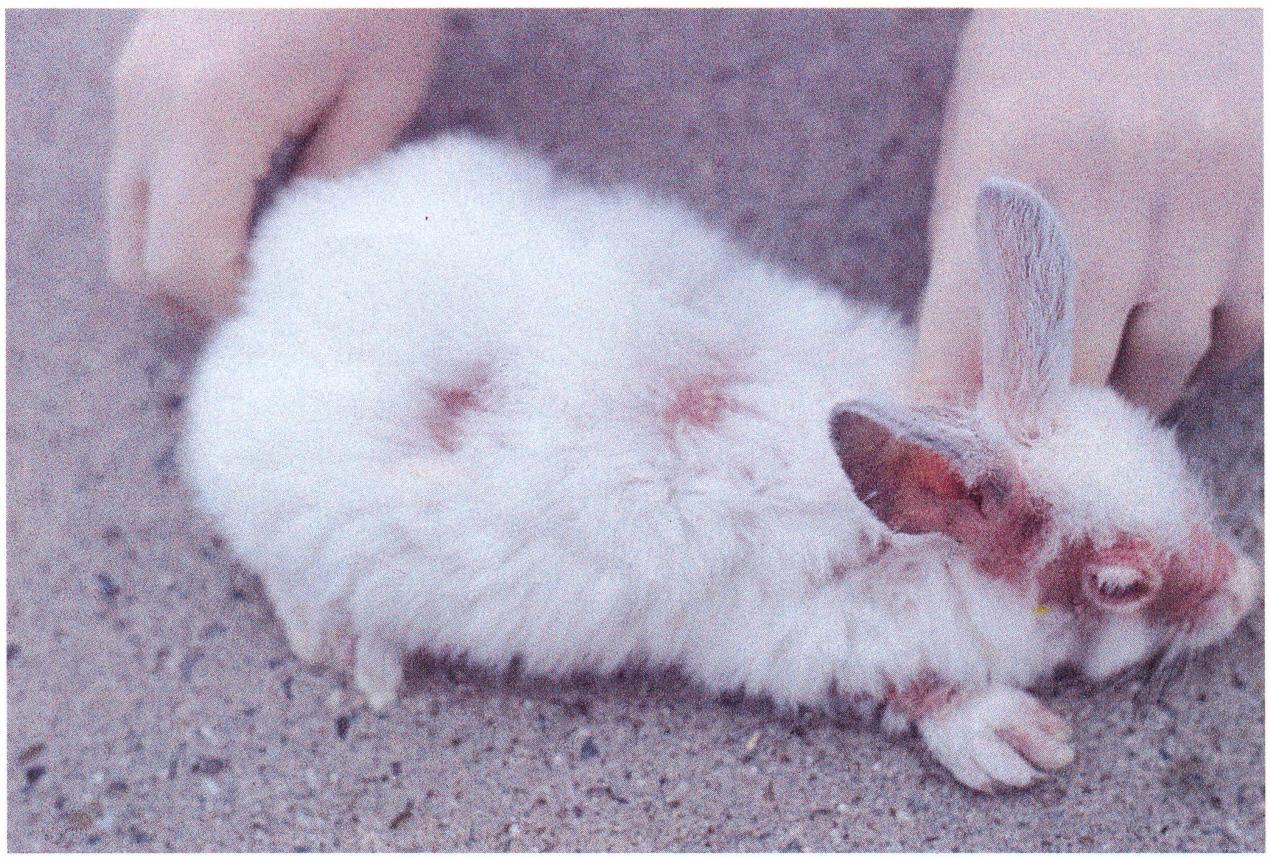

Fig. 1. Trichophytosis (T. mentagrophytes) in Hylla rabbits.

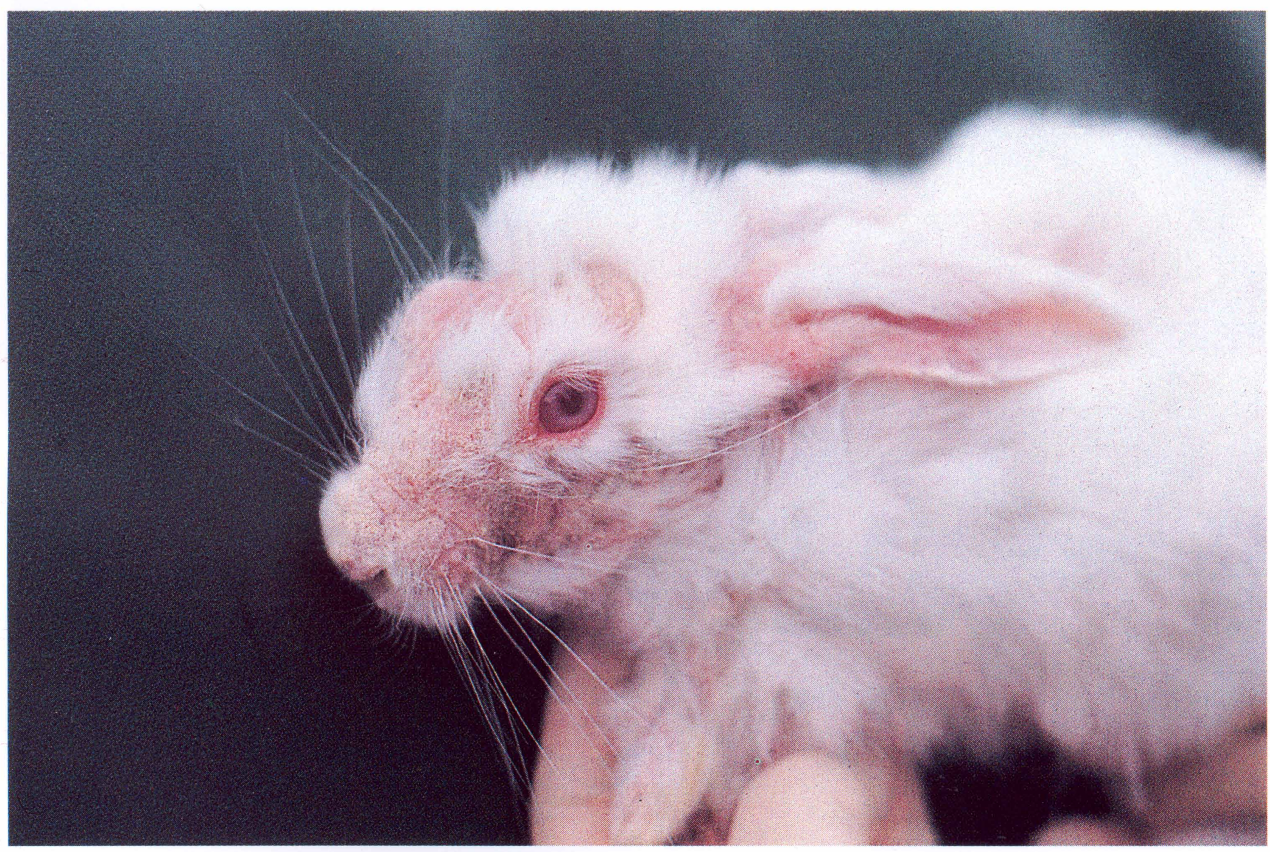

Fig. 2. Trichophytosis (T. mentagrophytes) in Cunistar rabbits. 


\section{Plate XI.}

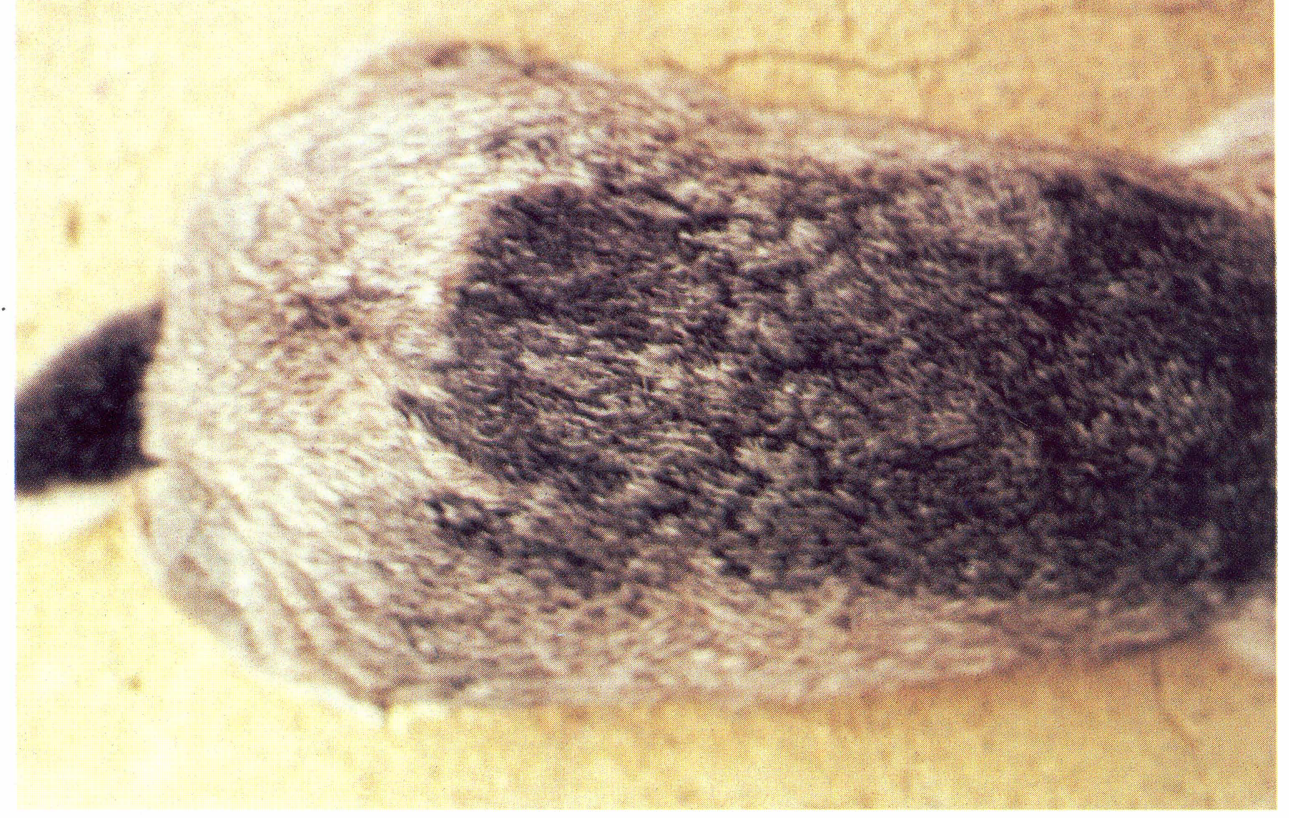

Fig. 3. Rabbit No. 8 vaccinated with TRICHOPELEN - Day 30 after challenge.

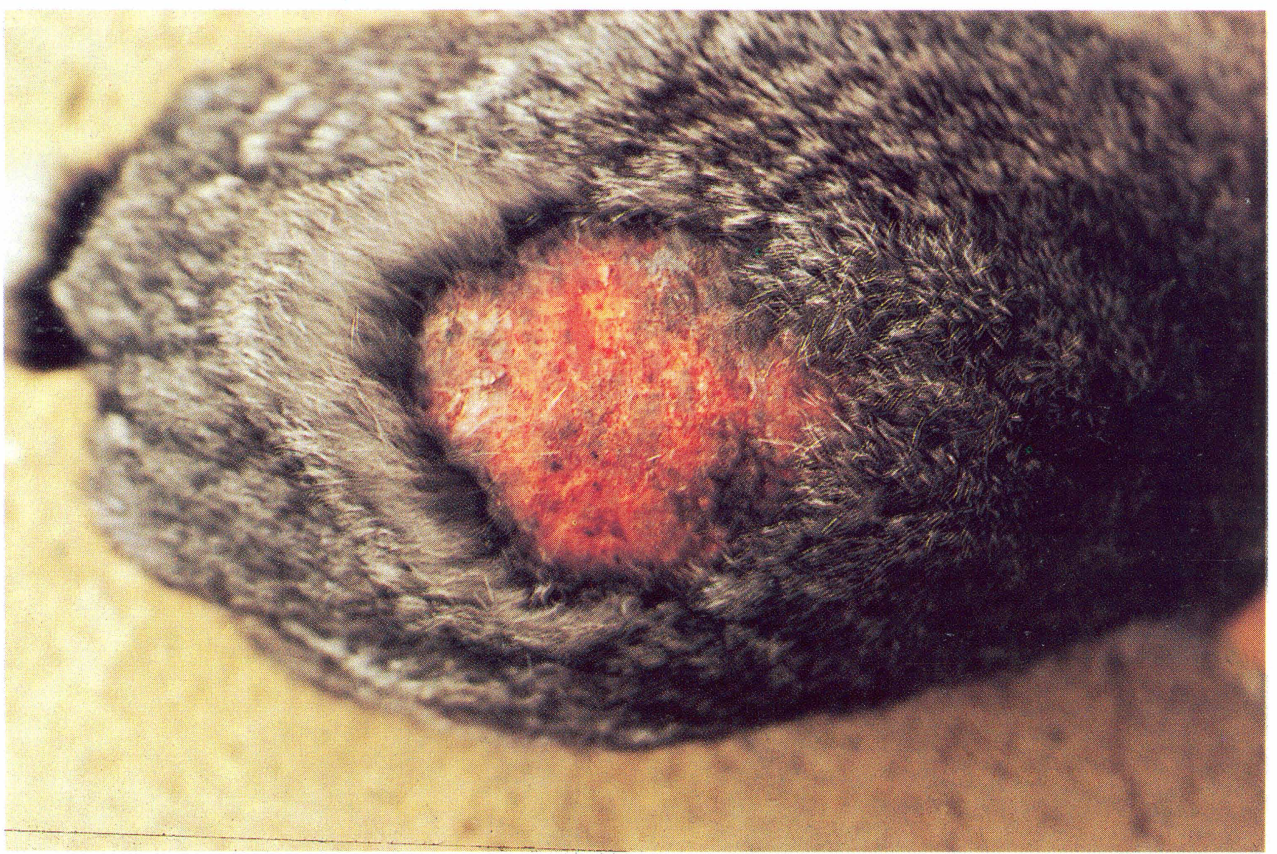

Fig. 4. Non-vaccinated control rabbit No. 25 - Day 30 after challenge. 